\title{
The nature and management of ethical corporate identity: Discussion paper on corporate identity, corporate social responsibility and ethics
}

\author{
Professor John M.T. Balmer \\ Professor of Corporate Brand/Identity Management \\ Bradford School of Management \\ England \\ UK \\ Dr Kyoko Fukukawa \\ Lecturer of Marketing \\ Bradford School of Management \\ England \\ UK \\ Professor. Edmund R. Gray \\ Professor of Management \\ Loyola Marymount University \\ Los Angeles \\ USA
}

\begin{abstract}
In this paper we open up the topic of ethical corporate identity: what we believe to be a new, as well as highly salient, field of inquiry for scholarship in ethics and corporate social responsibility. Taking as our starting point Balmer and Greyser's (2003) AC'ID test model of corporate identity - a pragmatic tool of identity management - we explore the specificities of an ethical form of corporate identity. We draw key insights from conceptualisations of Corporate Social Responsibility and social orientated theories of business. We argue ethical identity potentially takes us beyond the personification of the corporation as agent. Instead, ethical identity is seen to be formed relationally, between parties, within a community of business and social exchange. Extending the $A C^{2} I D$ test model, we suggest the management of ethical
\end{abstract}


identity requires a more socially, dialogically embedded kind of corporate practice and greater levels of critical reflexivity.

Keywords: $A C^{2} I D$ Test, Corporate Social Responsibility, Corporate Identity, Ethical Identity

\section{Introduction}

Adam Smith taught us, over 200 years ago, that capitalism is driven by individual greed and company profit maximization. But at the aggregate or system level, it results in a much wealthier economy where all its members benefit to varying degrees. Essentially, Smith provided us with the social justification for a business system populated by firms whose dominant goal is to increase the wealth of its owners.

Nonetheless, within our capitalistic system, there exists a small, but seemingly growing cadre of companies where social or ethical goals are preeminent or, at least, are on equal footing with the profit motive. Perhaps the earliest prototypes of such firms can be found in the $19^{\text {th }}$ century cooperative movements in Europe and the United States. For instance, the Co-operative Bank was chartered in 1872 to provide capital to the members of the Co-operative Wholesale Society in England. During the first half of the $20^{\text {th }}$ century, the bank deviated from its original charter and developed along conventional banking lines. In recent years, however, it has reversed this 
strategy and sought to revisit its original roots by establishing a social/ethical mission (Anonymous, 2003). In other words, the Co-operative Bank has made a conscious decision to project what we choose to call an "ethical identity".

There are a number of other firms with far different histories that have also established ethical identities. Recent formulations include companies trading under the increasingly popular banner of Fair Trade, developments in ethical investment and even a concept of 'authentic business', which at an entrepreneurial level makes explicit a company's core mission to go beyond that of profit-making (Croft, 2005). However, if ethical identity is to be accepted on a general basis as something more than a marketing gimmick, and with it becoming an increasingly attractive facet of mainstream corporate activity, there is undoubtedly a need to better understand the nature and managerial implications of ethical corporate identity. This paper represents a preliminary inquiry into this topic, and takes as its starting point Balmer and Greyser's (2003) AC'ID test model of corporate identity - a pragmatic tool of identity management. Added to which, we explore the specificities of an ethical from of corporate identity, drawing key insights from conceptualisations of Corporate Social Responsibility and social orientated theories of business. The argument we make is that ethical identity potentially takes us beyond the personification of the corporation as agent. Instead, ethical identity can be understood to be formed relationally, between 
parties, within a community of business and social exchange. Thus, extending the $\mathrm{AC}^{2} \mathrm{ID}$ test model, we suggest the management of ethical identity requires a more socially, dialogically embedded kind of corporate practice and greater levels of critical reflexivity.

\section{Notions of Corporate Identity}

'...corporations are always owed obligation to themselves to get large and to get profitable. In doing this, it tends to be more profitable to the extent it can make other people pay for the bills for its impact on society. There is a terrible word that economists use for this called "externalities"'

- Robert Monks (Corporate Governance Advisor), The Corporation

As legally defined, corporations are decreed to be a person in their own right, which has been a convenient social mechanism to allow corporations as their own entities to be liable for their actions. Such circumstance has certainly helped give rise to the concept of corporate identity, around which, over the past decade, a growing body of literature has emerged. This concept was originally used by identity or image consultants and was essentially defined as the image the organization is trying to project to its target stakeholders and the way it presents itself to these groups. Originally, as used by identity consultants, the term was synonymous with corporate logos and related graphics. Its meaning, however, was gradually 
broadened to comprehend a more total picture of the way organizations present themselves to their sundry stakeholders - through symbols, written and oral communication, and behavior (van Reil, 1995). The extension of the concept's meaning, of course, allowed the consultants to expand their services.

The corporate identity concept can also be found in the academic literature. Some academic writers use the term in the same way as do the consultants (van Reil, 1995; Marwick and Fill, 1997). Gray and Balmer (1998) suggested a more generic, but encompassing definition of corporate identity that opens up a promising new field (which includes the issues of corporate identity, image, reputation, and communication) to theory development and academic inquiry. In this way, corporate identity has been defined as the reality and uniqueness of the organization. Operationally, this is to say that a company's identity can be discerned through identifying its business strategy, its espoused values and philosophy, its organizational culture, and its structure. Thus, rather like the writing through the middle of a stick of rock candy, Corporate Identity ought to be in evidence throughout all aspects of a corporation's activities, regardless of when and where you 'cut in' to look at it. In other words, Corporate Identity is the signature that runs through the core of all a corporation does and communicates. Of course, unlike the 
simplicity of the message that reads through a stick of rock candy, Corporate Identity inevitably requires constant attention and management.

Balmer and Soenen's (1999) conceptual model of corporate identity begins in a pragmatic sense to map out the different aspects of an identity requiring management and alignment. They distinguish four discrete faces of identity: (1) actual: the current structural, organisational and philosophical attributes of a corporation; (2) communication, which is often described in relation to image and reputation, but importantly refers not only to "controllable" facets of corporate communication, but also the "noncontrollable" means of communication, e.g. word of mouth and media commentary; (3) desired: referring to what corporate management wants it to be; and (4) ideal, which refers to what objective outside analysts see as optimal positioning, i.e. the responsiveness to external factors and pressures. The model helps go beyond often more pervasive corporate thinking which considers identity as a monolithic phenomenon. Instead the model suggests corporate leaders recognise the co-existence of multiple perspectives and pressures related to a company's identity. Significantly, with respect to what we come to discuss with the concept of ethical identity, Balmer and Greyser (2003) extend the model of corporate identity (named as the AC'ID test) to include an aspect of 'conceived identity', which refers to 'the perceptions of the company - its multi-attribute and overall corporate image and corporate 
reputation - held by relevant stakeholders' (p.17). Managing conceived identity, they suggest, is all about making judgements 'as to which groups' perceptions are most important' (p.17).

This paper considers the development of a model of ethical corporate identity. As such, one critical implication, against the typical view of the corporation as a distinct, bounded identity, is that the management of others' perceptions can be just that, the management of others from the point of view of a single atomistic identity. Yet, if we understand ethics, by default, always to ask questions not simply of ourselves, but how we relate to others in the world around us (and hence why we might find ourselves in ethical dilemmas), we perhaps need to begin to consider more social, dialogical models of the corporation.

Taken as a whole, the different faces of identity described by Balmer and his collaborators begin to help us consider perhaps four main themes or questions pertinent to the notion of ethical corporate identity: (1) Who are we?; (2) How do we communicate our identity?; (3) How is our identity conceived by others?; finally, and most pertinent to our discussion here, (4) How are we to understand identity as a holistic phenomenon? A key theme common to these questions is the internal/external nature of a corporation's identity. The actual identity of a corporation is described as current attributes 
as shaped by corporate ownership, leadership, organisation and performance.

At the heart of actual identity - to be asked by owners, managers, and employees alike - is the fundamental question 'who are we?' - leading, no doubt, in compliment to desired and ideal identity, to the question of 'who do we want to be?'. Crucially, as described by the AC'ID test model, these are questions posed as part of internal debate within company management and operations. Similarly, communicated identity - though asking the question of how to become identified by others - is directed from within a company, with perhaps the media as interpreters or translators of a company's desired message. Conceived identity, on the other hand, relates to the external manifestation of a corporation's identity, stemming from a company's relationship and placement within wider public contexts. Arguably a greater shift towards the external articulation of identity is required with respect to any purported ethical corporate identity. Furthermore, since bridging the internal and external will inevitably lead to the need of an increasingly fluid model of identity, it is surely of considerable benefit to consider identity, its communication and conception in a more holistic manner.

The important point stressed by identifying different aspects of identity is that there is no one single perspective, in fact it would be highly reductive to suggest otherwise. Balmer and Greyser (2003, p.16) pertinently note that 'corporate leadership should recognize that multiple identities can co-exist 
within a company even if they are slightly different'. However, in going a little further, the argument we establish in consideration of the notion of ethical corporate identity is that we need to re-evaluate the grounds of the terms we are using, to attempt a further holistic consideration that places the corporation within a relational, networked system of meanings, values and identities. As we go on to consider, the varying phases of corporate social responsibility and social orientated theories of business (notably here stakeholder theory) can aid us in bridging matters of ethics with the insights of Balmer and Greyser's AC'ID test model of corporate identity. Interestingly, in the concluding line of Balmer and Greyser's (2003, p.27) article outlining the model, they suggest ' $[t]$ he ultimate guardians and managers of corporate identity reside in the boardroom'. If there is one underlying, foundational point raised in our discussion here on ethical corporate identity, it is to challenge this statement, not so as to undermine it, but to extend our thinking, to ask how the management of corporate identity is connected to a wider sphere of influences and actions.

\section{Placing Ethical Corporate Identity (vis-à-vis models of CSR and Stakeholder Theory)}

At first look, perhaps, the turn towards ethical corporate identities perhaps need not mean any real adjustment from how we conceptualise 
corporate identity more generally. Indeed, ethical identity has been successfully actualised by numerous companies, generally being a constituent component of what they actually trade in. So, for example, companies such as Innocent (fruit drink company), Cafédirect, Triodos Bank, Co-Operative Bank, Green \& Black's (Organic fair trade chocolate) and clothing companies Hug and Howies, all define, organise and structure their business in terms specific to their ethical interests and, furthermore, make this a part of how they then position themselves in the marketplace. As Clark (2006) has argued, the food and drink sector has been particularly successful in developing brands with a strong ethical identity, in this case usually placing emphasis upon quality and provenance of produce. However, in 'going ethical' - in being very explicit about ethical practice - there is perhaps an argument to be made that a company's communicated identity is evermore significant. Indeed it is likely that non-controllable communication is in need of increased attention. When recently, for example, the cosmetics giant L'Oréal bought up the Body Shop, a brand famed for its ethical stance, it was inevitable that media attention would bring to the fore questions regarding the wisdom of the acquisition and that dissenting voices would be heard from various animal rights groups. The PR machines were no doubt working hard the day of the handover, ensuring the high visibility in media reports of the original founder and spokesperson for the Body Shop, Dame Anita Roddick. 
L'Oréal's acquisition of the Body Shop (and the generous price they paid for it) is symptomatic of a trend in the mainstreaming of ethical businesses. However, it is equally significant in this case, when considering the specifies of ethical identity, L'Oréal were quick to point out there were no plans to merge with the Body Shop; instead it was declared the brand is to remain a standalone business. So, what is at stake in owning and maintaining an ethical identity - what is it that makes them different? To shed some light on this question it is helpful to reflect on the changing conceptualisations (and fortunes) of CSR. Maignan and Ferrell (2004) provide a cogent overview of the various perspectives on CSR, dating back to 1950s. In its earliest manifestation, CSR is characterised by a sense of social obligation; 'to follow those lines of action which are desirable in terms of the objectives and values of our society' (Bowen, 1953, p.6). Carroll (1979) later develops this idea with a model of different types of CSR, to include: economic responsibility, legal and ethical responsibility, and philanthropic responsibility. From their inception, corporations have always held a responsibility to stay in business, i.e. to be economically sound. In addition, of course, corporations are legally required to comply with existing laws and to acknowledge social values and norms (to respond to what society expects of them).

Ethical responsibilities of a corporation concern what is right, just and fair, but which are not necessarily bound up with any existing legal framework; responsibilities, then, which arise from specific cultural contexts. 
Philanthropic responsibility, however, arises out of a specific philosophical, ethical tradition, being concerned with what is good for a society as a whole, and seemingly provides a mechanism for corporations to help improve the quality of life for different (and often underprivileged) parties and communities in the society.

Part of the challenge of ethical identity, however, has been to move on from philanthropic activity, which it can be argued has come to be viewed as 'a paternalistic expression of corporate power' (Swanson, 1995, p.50). More generally, with society in the late $20^{\text {th }}$ century having become much more fragmented, though also arguably far more equitable, Maignan and Ferrell (2004) note how the notion of social obligation has been seen to be too broad a notion to promote effective CSR management. Thus, from the mid-1990s, a more tailored definition of corporate responsibility emerged, to suggest 'businesses are not responsible toward society as a whole but only toward those who directly or indirectly affect or are affected by the firm's activities' (Maignan and Ferrell, 2004, p.4). This has been to mark a shift from social to stakeholder obligation. Drawing on the work of Henriques and Sadorky (1999), Maignan and Ferrell (2004) suggest four main catergories of stakeholder: (a) organisational (to include employees, customers, shareholders, suppliers etc.); (b) community (e.g. local residents and interest groups); (c) regulatory bodies; and (d) media stakeholders. Clearly, while 
corporations need not be considered responsible to society as a whole, stakeholder obligations are nevertheless extensive and bring into focus numerous and varied concerns, as well as potential conflicts.

Whilst there is actually no single definitive theory of the stakeholder, 'each version generally stands for the same principle, namely that corporations should heed the needs, interests, and influence of those affected by their policies and operations' (Buchholz and Rosenthal, 2005, p.137). For advocates of social responsibility, stakeholder theory has been of particular interest, since it has enabled a re-definition of how business relates to society. Thus, against the traditional economic view, which considers the corporation to relate to society only through the marketplace, with stockholders the primary, if not the only stakeholders of importance, following stakeholder theory a more even view is taken, with stockholders becoming only one among various stakeholders. As a consequence of which, the very purpose of a firm theoretically shifts 'to serve and coordinate the interests of its various stakeholders, and it is the moral obligation of the firm's managers to strike an appropriate balance among stakeholder interests in directing the activities of the firm' (Buchholz and Rosenthal, 2005, p.138). Inevitably this presents all sorts of ramifications for notions of identity. 
Thus, in relating stakeholder theory to a more specific interest in ethical corporate identity, the aspect of conceived identity noted in Balmer and Greyser's (2003) work not only helps bring to the fore the importance of a company's external face, but more significantly alerts us to the idea that one's identity need not always be neatly 'located' within the company. In other words corporate identity - rather like individual identity - can not be said to be solely based in some core essential entity that simply emits its distinctive character. Instead identity is formed as much in the mirror of another's perceptions, with this reflection being as much an influencing factor in how a corporation behaves and asserts its identity. Wicks et al. (1994) feminist reinterpretation of stakeholder theory - which draws upon a trope of 'caring' - leads towards a definition of the corporation as made up of a web of relations among stakeholders, suggesting that internal/external distinctions then fade. Fundamentally, Wicks et al (1994) urge for a new definition of the corporation (and indeed of the self) that is based upon its relational nature, and not some essentialist or atomistic principle.

As Buchholz and Rosenthal (2005, p.144) explain, shifting to a relational understanding of managing for stakeholders does not mean to say competition then becomes irrelevant, though perhaps it does becomes something of a secondary virtue. Instead, '[a] firm becomes competitive as an 
effect of successful collaboration and team work', which in turn is to suggest a change in the "logical place" of competition in any network:

While a firm must be able to compete to survive, survival requires growth, growth requires enhancement of a relational web, and the direction growth takes evolves through the self-direction of the firm's community dynamics. Moreover, community growth cannot be measured in economic terms alone, because it involves the enrichment of human life in its entirety. The moral meaning of the firm is rooted in the community dynamics by which life thrives and in which the experience of value and its furtherance emerges (Buchholz and Rosenthal, 2005, p.145).

Acknowledgement of this kind of thinking - of understanding business strategy as part of a relational network - has arguably been in evidence with a group of high profile British companies recently brought together by the Prince of Wales' Business and Environment Programme. The group, which included executives from Shell, Tesco, Vodafone, BAA and Standard Chartered Bank, held a meeting with the British Prime Minister (in June 2005) to urge more restrictions are set with regards to carbon dioxide emissions, suggesting, for example, the need for tougher regulations on low-energy homes and products. As part of the thinking behind their request is the idea that growth requires enhancement of matters beyond the economic. The group claim, for example, that developing countries will not take climate change seriously unless countries like the UK show how it can be tackled. ${ }^{1}$

\footnotetext{
${ }^{1}$ Source: 〈http://news.bbc.co.uk/2/hi/uk_news/5050774.stm>
} 
However, stakeholder theory is certainly not without its problems. As part of Maignan and Ferrell's (2004) overview of the conceptualisations of CSR, they suggest the need to look beyond both social and stakeholder obligations. Not least because, 'the view of CSR as an obligation fails to provide normative criteria to evaluate the extent to which actual business practices can or cannot be considered as socially responsible' (p.4, emphasis added). How, for example, can we evaluate the delegation noted above, who took it upon themselves to urge the British government for stiffer environmental sanctions? On what basis and due to what kinds of motivations has this group of notable companies made sense of the complex issues at stake? In trying to examine and define the concept of ethical identity, Stakeholder theory presents us with a certain blind-spot, since the theory depends very much on how you define the corporate entity in the first place. In fact, whilst stakeholder theory has sought to 'correct' the traditional economic view of the corporation as solely premised upon the interests of its stockholders, all too frequently it 'remains rooted in the same atomistic individualism that pervades traditional economic theory' (Buchholz and Rosenthal, 2005, p.146). Thus, stakeholder theory does not readily extend the view beyond that which maintains the corporation as an autonomous agent, that 'the basic identity of the firm is defined independent of, and separate from, its stakeholders' (Buchholz and Rosenthal, 2005, p.138). 
The root of the problem is perhaps that the concept and role of the stakeholder, whilst widely adopted, remains 'fuzzy'; leading Antonacopoulou and Méric (2005), for example, to suggest we need to look past its 'scientific' applicability and begin to look more closely at its ideological assumptions. As they explain, their critique does not aim to 'dismiss the possibilitiy that stakeholder theory as an ideology of caring relationships and interdependencies would add value' (p.30). Nevertheless, they take issues with the fact that stakeholder theory - no doubt like theories of CSR and Corporate Identity - can too readily be considered to be value free. Thus mirroring what Maignan and Ferrell (2004) observe as a more recent 'ethicsdriven' view of CSR (that takes its bearings direct from philosophical debate and theory), Wicks et al. (1994) interpretations vis-à-vis feminist theory and Buchholz and Rosenthal's (2005) consideration of social pragmatism present useful relational philosophies which help to critique (and decentre) the notion of the responsible corporate entity (or agent). As a result, we can begin to conceptualise the corporation as intricately bound up in and with community, so like the individual, is 'neither an isolatable discrete element in, nor an atomic building block of, a community' (Buchholz and Rosenthal, 2005, p.143). A question remains as to how we can understand such ideas to be opertionalised in terms of ethical corporate identity. 
The notion of a decentred, relational identity need not at all be considered a necessarily contemporary configuration. In Aristotle's writings, for example, there is a clear sense of the self as being inseparable from their surroundings - and importantly as necessary for the make-up of a moral person. The Greek word for someone uninterested in public life is translated as 'idiot', from which we get the word 'idiosyncratic' - i.e. to hold only to one's own sense of self. By contrast the Greek democrat was someone who belonged to the city, i.e. was a citizen (McAfee, 2000, p.3):

'The city-state is also prior in nature to the household and to each of us individually, since a whole is necessarily prior to its parts. For if the whole body is dead, there will no longer be a foot or a hand ... Anyone who cannot form a community with others, or who does not need to because his is self-sufficient, is not part of a city-state - he is either a beast or a god' (Aristotle, 1998, 4-5).

Aristotle's explanation of the good citizen clearly relates well to the ideas noted above for corporate identity to come through a network of relations; and surely it opens up an interesting avenue for research over the concept of corporate citizenship. Specific to our discussion of ethical corporate identity, and to further this need to apply greater scrutiny to the concepts of CSR, ethics and stakeholders, we might usefully keep in mind the importance of the philosophic tradition that Aristotle is placed within. The practice of philosophy is to be critically engaged in the world, to test ideas to their limits, indeed to offer continual critique. It is this ability in critical reflexivity that 
Antonacopoulou and Méric (2005) argue must to be at the centre of any consideration of theories such as stakeholder theory; and in order that:

'...greater conscientization on the values underlying knowledge production processes in management and organization studies can lead to more insight and pragmatic representations of these complex and multifaceted aspects of social relations that stakeholder theory [as with other socially-oriented theories are] committed to address' (p.31).

Similarly, as alluded to above, critics of social and stakeholder obligations models of CSR advocate what Maignan and Ferrell (2004) describe as an 'ethics-driven view of CSR'. In which case, the practice of CSR is based more specifically upon deeper philosophical debates of justice-based ethics, so, for example, allowing a company to 'attempt to systematically favour decisions and procedures that stimulate equality, liberty, and fairness of opportunity for its various partners and associates' (p.4).

Just how greater critical reflexivity can be achieved in the corporate environment remains a rather open question. Perhaps, like the anthropologist who comes in from the outside as a critical observer, but who nonetheless seeks to meld with the crowd, corporations need to employ critical thinkers, who are then left free to roam (and interact) with their own agendas. However, to focus upon current managerial contexts, and to return to Balmer 
and Greyser's (2003) model of corporate identity (specifically designed as a tool for managerial decision-making), there are various considerations and recommendations that can likely be made. Based upon the above considerations of CSR and Stakeholder Theory, we are certainly led towards an interesting, and perhaps even a radical, model of corporate ethical identity. Crucially, if we again remind ourselves of Balmer and Greyser's (2003, p.27) line that ' $[t]$ he ultimate guardians and managers of corporate identity reside in the boardroom', we need to ask more concretely how such guardians actually seek to connect (and be seen to connect) with their externalities. Certainly we would want to agree, as Balmer and Greyser also note in their concluding remarks, that 'regular identity reviews warrant a place on the senior management's agenda' (p27). As difference of emphasis, however, it might be pertinent to remind ourselves - and by the same token to remind managers - that when it comes to the domains of ethics, we can't always been seen to be setting the agenda. Ethics is a matter between parties, not for one party to bestow upon another. The task, then, for the corporation is somehow to capture for practical ends this relational process and interchange that ethics always engenders upon us.

\section{Concluding Remarks}


Crucially, ethical identity would seem to go beyond the problem of personification that rather besets any view of the corporation as having agency. Instead, ethical identity is seen to be formed relationally, between parties, within a community of business and social exchange; though ostensibly to be managed through new levels of critical reflexivity on the behalf of a corporation. At present, we perhaps best need to see the relationship between CSR and Corporate Identity as opening up an important new area for future research. In fact, arguably, there is perhaps no such thing as ethical corporate identity, but instead ethical identifications (or preferences) that are expressed and reflected upon between stakeholders. In other words, ethical identity - if we were to 'place' it within Balmer and Greyser's (2003) model of corporate identity - is formed externally, or relationally between points, with conceived identity a significant element affecting its configuration and maintenance. Thus, if ask the question headon, 'What is Ethical Identity?', it is certainly the case that ethical identity is not simply the stating of (and even following through with) ethical values and principles in a corporate mission statement, or a code of ethics. Instead, corporations are identified as being ethical by their social connectedness, critical reflexivity and responsiveness. Alignment between actual, desired, communicated, ideal and conceived identity becomes ever more critical, but more crucially still, not as to define an atomistic identity of a single corporate 
agent, but rather to identify a more socially, dialogically embedded kind of corporate practice.

More work undoubtedly needs to be done to determine properly how the AC'ID test model - as a pragmatic tool of corporate managers - can be operationalised within the extended, more fluid framework we consider here of ethical corporate identity. If there is a specific sticking point it perhaps relates to the dimension of actual identity, which arguably is framed in overly static terms, as a snapshot, as it were, of a corporation as a whole. It is not to suggest that such moments of actualisation are not in evidence, but in extending the model to ethical corporate identity - and with the hope to sharpen further the $\mathrm{AC}^{2} \mathrm{ID}$ test model - it would perhaps be more pertinent to view actual identity as only single moments in a far more complex series of exchanges. Undoubtedly, like the photo-journalist's dramatic freeze-frame of a 'moment of truth', actual identity can be both convincing and appealing indeed an important driver for ethical leadership. Yet, like the still image, we have to remember all kinds of contributing (and even conflicting) action goes on in and around the frame before and after any one single image is held. In philosophical terms - which, following the ethics-driven view of CSR, we may rightful indulge in - there is at stake a difference between being and becoming (or doing): A difference, then, between simply asserting a corporate identity and actually sharing (even living) an ethical corporate identity. 


\section{References}

Anonymous (2003) 'Co-op has credibility but needs fresh look' in Marketing, June 23, p.13.

Antonacopoulou, E.P. and Méric, J. (2005) ‘A Critique of Stake-holder Theory: Management Science of a Sophisticated Ideology of Control?' in Corporate Governance, Vol. 5, No. 2, pp. 22-33.

Aristotle (1998) Politics. Trans. by C.D.C. Reeve. Indianapolis: Hackett.

Balmer, J.M.T., and Soenen, G.B. (1999), “The Acid Test of Corporate Identity Management," Journal of Marketing Management, vol. 15, pp. 69-92.

Balmer, J.M.T, and Greyser, S.A. (2003), “Managing the Multiple Identities of the Corporation," in Balmer and Greyser (ed.) Revealing the Corporation. London and New York: Routledge, pp. 15-29.

Buchholz, R.A. and Rosenthal, S.B. (2005) 'Toward a Contemporary Conceptual Framework for Stakeholder Theory' in Journal of Business Ethics, 58: 13-148.

Clark, N. (2006) 'Going the Extra Mile', in Marketing, May 4, p18.

Croft, N (2005) Authentic Business. Chichester: Capstone Publishing Limited 
Gray, E.R. and Balmer, J.M.T. (1998), “Managing Corporate Image and Corporate Reputation," Long Range Planning, vol. 31, October, pp. 695702.

McAfee, N (2000) Habermas, Kristeva, and Citizenship. Ithaca and London: Cornell University Press.

Maignan, I. and Ferrell, O.C. (2004) ‘Corporate Social Responsibility and Marketing: An Integrative Framework' in Journal of the Academy of Marketing Science, Vol. 32, No. 1, pp. 3-19.

Marwick, N. and Fill, C. (1997), “Toward a Framework for Managing Corporate Identity," European Journal of Marketing, vol. 31, no. 5/6, pp. 396-409.

Van Riel, C.B.M. (1995), Principles of Corporate Communication, PrenticeHall, Hemel Hempstead, U.K. 